\title{
DIAGNOSTIC CHARTING ON PANORAMIC RADIOGRAPHY USING DEEP- LEARNING ARTIFICIAL INTELLIGENCE SYSTEM
}

\author{
Melike Başaran ${ }^{1}$, Ozer Celik ${ }^{2}$, İbrahim Bayrakdar ${ }^{3}$, Elif Bilgir ${ }^{4}$, Kaan Orhan ${ }^{5}$, Alper \\ Odabaş $^{2}$, and Ahmet Faruk Aslan ${ }^{2}$ \\ ${ }^{1}$ Kütahya Sağlık Bilimleri Üniversitesi \\ ${ }^{2}$ Eskişehir Osmangazi University Department of Mathematics and Computer Science \\ ${ }^{3}$ Eskisehir Osmangazi Universitesi \\ ${ }^{4}$ Eskişehir Osmangazi Üniversitesi \\ ${ }^{5}$ Ankara University Faculty of Dentistry
}

January 20, 2021

\begin{abstract}
Aims of the Study: A radiographic examination is a significant part of the clinical routine for the diagnosis, management, and follow-up of the disease. Artificial intelligence in dentistry shows that the deep learning technique high enough quality and effective to diagnose and interpret the images in the dental practice. For this purpose, it is aimed to evaluate diagnostic charting on panoramic radiography using a deep-learning AI system in this study. Methods: 1084 anonymized dental panoramic radiographs were labeled for 10 different dental situations including crown, pontic, root-canal treated tooth, implant, implantsupported crown, impacted tooth, residual root, filling, caries, and dental calculus. AI Model (Craniocatch, Eskişehir, Turkey) based on a deep CNN method was proposed. A Faster R-CNN Inception v2 (COCO) model implemented with Tensorflow library was used for model development. The training and validation data sets were used to predict and generate optimal CNN algorithm weight factors. Results: The proposed artificial intelligence model has promising results for detecting dental conditions in panoramic radiographs except for caries and dental calculus. The most successful F1 Scores were obtained from the implant, crown, and implant-supported crown as 0,9433, 0,9122, 0,8947, respectively. Conclusion: Thanks to the improvement of the success rate of AI models in all areas of dentistry radiology, it is predicted that they will help physicians especially in panoramic diagnosis and treatment planning, as well as digital-based student education, especially in this pandemic period when online training is on our agenda.
\end{abstract}

\section{RESEARCH ARTICLE}

\section{DIAGNOSTIC CHARTING ON PANORAMIC RADIOGRAPHY USING DEEP- LEARN- ING ARTIFICIAL INTELLIGENCE SYSTEM}

Melike Başaran, DDS, $\mathrm{PhD}^{1}$, Özer Çelik, $\mathrm{PhD}^{2}$, Ibrahim Sevki Bayrakdar DDS, $\mathrm{PhD}^{3}$, Elif Bilgir, DDS, $\mathrm{PhD}^{4}$, Kaan Orhan DDS, $\mathrm{PhD}^{5,6}$, Alper Odabaş, $\mathrm{PhD}^{7}$, Ahmet Faruk Aslan, $\mathrm{PhD}^{2}$

${ }^{1}$ Assistant Professor, Department of Oral and Maxillofacial Radiology, Faculty of Dentistry, Kütahya Health Science University, Kütahya, Turkey

2 Assistant Professor, Department of Mathematics-Computer, Eskisehir Osmangazi University Faculty of Science, Eskisehir, Turkey 
3 Associate Professor, Department of Oral and Maxillofacial Radiology, Faculty of Dentistry, Eskisehir Osmangazi University, Eskişehir, Turkey

4 Assistant Professor, Department of Oral and Maxillofacial Radiology, Faculty of Dentistry, Eskisehir Osmangazi University, Eskişehir, Turkey

${ }^{5}$ Professor, Department of DentoMaxillofacial Radiology, Faculty of Dentistry, Ankara University, Ankara, Turkey

6 Ankara University Medical Design Application and Research Center (MEDITAM), Ankara, Turkey

7 Associate Professor, Department of Mathematics and Computer Science, Faculty of Science, Eskisehir Osmangazi University, Eskisehir-Turkey

Running Title: artificial intelligence on panoramic radiographs

Address for correspondence/reprints:

\section{Dr. Ibrahim Sevki Bayrakdar}

Department of Oral and Maxillofacial Radiology, Faculty of Dentistry, Eskisehir Osmangazi University, 26240, Eskişehir, TURKEY

Business telephone number: 00902222391303 Fax number: 00902222391273

E-mail:ibrahimsevkibayrakdar@gmail.comORCID ID: 0000-0001-5036-9867

Melike Başaran

E-mail: basarannm@gmail.com ORCID ID: 0000-0002-3311-1642

Özer Çelik

E-mail: ozercelik05@gmail.com ORCID ID: 0000-0002-4409-3101

\section{Elif Bilgir}

E-mail: bilgirelif04@hotmail.com ORCID ID: 0000-0001-9521-4682

\section{Kaan Orhan}

E-mail: call53@yahoo.com ORCID ID: 0000-0001-6768-0176

\section{Alper Odabaş}

E-mail: aodabas@ogu.edu.tr ORCID ID: 0000-0002-4361-3056

\section{Ahmet Faruk Aslan}

E-mail: afaslan@ogu.edu.tr ORCID ID: 0000-0003-1583-6508

\section{Hosted file}

KO edited.pdf available at https://authorea.com/users/390822/articles/505045-diagnosticcharting-on-panoramic-radiography-using-deep-learning-artificial-intelligence-system 


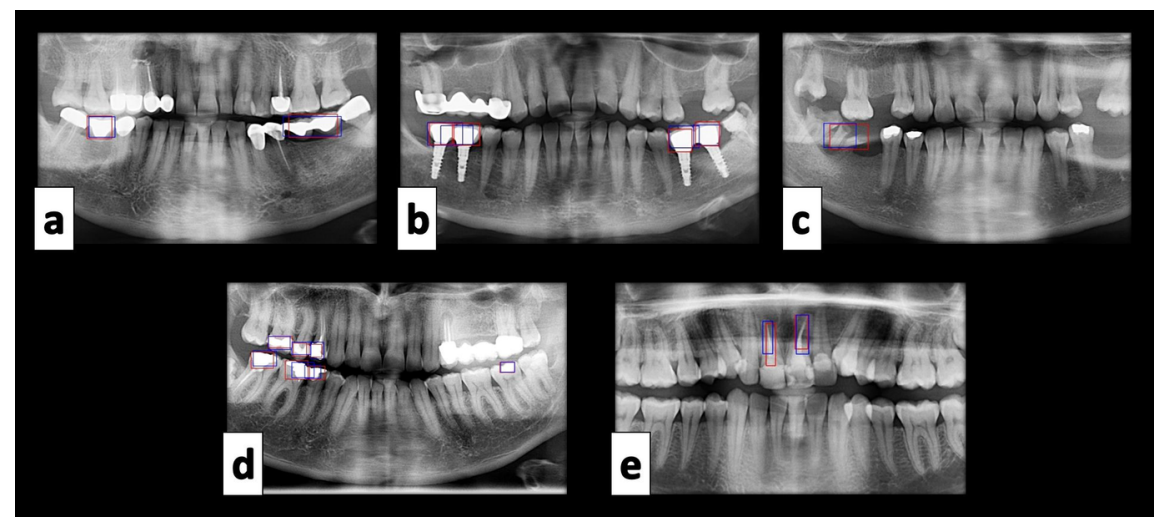

\section{Hosted file}

table 1.pdf available at https://authorea.com/users/390822/articles/505045-diagnosticcharting-on-panoramic-radiography-using-deep-learning-artificial-intelligence-system

\section{Hosted file}

table 2.pdf available at https://authorea.com/users/390822/articles/505045-diagnosticcharting-on-panoramic-radiography-using-deep-learning-artificial-intelligence-system 